\title{
TINGKAT PEMBERDAYAAN USAHA GARAM RAKYAT (PUGAR) DITINJAU DARI ASPEK PRODUKSI, DISTRIBUSI, PERMINTAAN PASAR DAN SOSIAL BUDAYA
}

\author{
Ratih Setyaningrum*), Ariati Anomsari, Eko Hartini ,Herwin Suprijono \\ Universitas Dian Nuswantoro \\ Jl. Nakula I No. 5-11 Semarang
}

\begin{abstract}
Abstrak
Penerapan program pemberdayaan usaha garam rakyat (PUGAR) untuk mengintensifkan lahan garam dan mendongkrak produktivitas garam rakyat dinilai lamban. Program Pemberdayaan Usaha Garam Rakyat (PUGAR) perlu diberdayakan lagi sehingga mampu meningkatkan kesejahteraan petani garam dan mensukseskan swasembada garam industri pada tahun 2015. Tujuan penelitian ini adalah menganalisis pemberdayaan usaha garam rakyat (PUGAR) berdasarkan aspek produksi, distribusi, permintaan garam industri Jawa Tengah. Menentukan tingkat pemberdayaan usaha garam rakyat di wilayah Jawa Tengah. Penelitian dilakukan dengan membagikan kuisioner kepada petani gara, melakukan FGD dan wawancara kemudian melakukan analisis teknis untuk menentukan tingkat pemeberdayaan dan strategi pemeberdayaan. Hasil yang diperoleh adalah aspek produksi yang berkaitan dengan teknologi tingkat keberdayaan rendah, aspek distribusi, dan permintaan pasar rendah serta aspek sosbud dan keberlanjutan usaha tinggi.Aksi tindak prioritas jangka pendek adalah optimalisasi teknologi terapan untuk proses produksi, perbaikan rantai distribusi dan informasi pasar yang berkelanjutan sehingga tercipta stabilitas usaha garam rakyat.
\end{abstract}

Kata kunci: tingkat keberdayaan, produksi, distribusi, pasar, sosial budaya

\begin{abstract}
PUGAR activities to improve productivity concidered slowly. PUGAR need to be empowered again, to improve the welfare of farmers and the success of self-sufficiency salt industry in 2015. The purpose of this study is to analyze the people's business empowerment (PUGAR) based on aspects of production, distribution, demand for industrial salt in Central Java. Determining the level of empowerment of the salt business people in Central Java. The study was conducted by distributing questionnaires to farmers, conducting FGD and interview. A technical analysis to determine the level and strategy for empowerment. The result is production aspects related to the empowerment of low-level technology, aspects of distribution, and market demand is low, but socio-cultural aspects and sustainability efforts ishigh level. . pro short-term priority is to optimize the technology applied to the production process, improving the distribution chain and sustainable market information so as to create stability salt business people.
\end{abstract}

Keyword: empowered level, production, distribution, market, socio-cultural

\section{Pendahuluan}

Indonesia adalah negara kepulauan yang memiliki wilayah perairan yang sangat luas yang terdiri dari 17.508 pulau dengan panjang garis pantai $81.290 \mathrm{~km}$. Luas wilayah laut Indonesia sekitar $5.176 .800 \mathrm{~km} 2$. Ini berarti luas wilayah laut Indonesia lebih dari dua setengah kali luas daratannya. Namun potensi laut yang melimpah belum bisa dioptimalkan, hal ini terbukti dengan

\footnotetext{
${ }^{*}$ Penulis Korespondensi. email: ratihha@gmail.com
}

J@TI Undip, Vol X, No.1, Januari 2015 import garam. Negara kita yang terdiri dari lautan masih saja mengimport garam dari luar negeri hal ini sangat memalukan dan tidak sewajarnya bangsa Indonesia yang tidak bisa mengoptimalkan produksi alamnya yang sangat melimpah dan juga mempengaruhi pendapatan suatu daerahnya. Produksi garam dalam negeri hingga awal September 2011 tercatat mencapai 308.355 ton sehingga diperkirakan dapat memenuhi target produksi garam pada 2011. Dari jumlah tersebut, sebanyak 133.457 ribu ton di antaranya telah terserap oleh pasar dan stok garam saat ini adalah 174.898 ton dan untuk stok tahun 2012 belum terpenuhi (kompas,2012). 
Penerapan program pemberdayaan usaha garam rakyat (PUGAR) untuk mengintensifkan lahan garam dan mendongkrak produktivitas garam rakyat dinilai lamban. Penyaluran bantuan itu baru turun memasuki musim panen garam. Program Pemberdayaan Usaha Garam Rakyat (PUGAR) perlu diberdayakan lagi sehingga mampu meningkatkan kesejahteraan petani garam dan mensukseskan swasembada garam industri pada tahun 2015.

Pada penelitian ini, sustainable manufacturing meliputi proses pengolahan dari hulu hingga hilir, pengolahan air laut menjadi garam menggunakan teknologi ramah lingkungan yang tidak tergantung sinar matahari. Kelebihan metode tersebut yakni produk garam akan stabil pada cuaca panas maupun hujan. Hal tersebut sejalan dengan Predeep (2013) menyatakan bahwa industri harus merumuskan inovasi berkelanjutan dalam bentuk sustainable manufacturing dengan pendekatan aspek sosial, ekonomi dan lingkungan. Selaras dengan Rosnah (2013) menyatakan bahwa managemen perlu dievalusi dari sisi proses sustainable, sustainability performance dan sustainabilityperformace analisis. Teknologi reverse osmosis dan mikrokontroler berfungsi mengubah air laut menjadi air tawar. Mikrokontroler akan mengatur inlet air laut dan arus outlet air limbah. Mikrokontroler juga memonitor besarnya tekanan air yang bekerja pada sistem untuk mengetahui kualitas produk dari reverse osmosis.

Optimalisasi proses pengolahan air laut menjadi garam menggunakan metode sustainable manufacturing dengan teknologi reverse osmosis microcontroler ditargetkan akan meningkatkan upaya pemberdayaan usaha garam rakyat (PUGAR) dari aspek produksi. Disamping itu upaya pemberdayaan diidentifikasi dari aspek ekonomi, sosial dan pemasaran. Hal tersebut sejalan dengan Anomsari dan Setyaningrum (2012) yang meneliti usaha pemberdayaan batik semarang.

Upaya mengoptimalkan pengolahan garam mutlak dilakukan, mengingat kondisi yang ironis yakni Indonesia memiliki lautan luas melakukan import garam dalam jumlah yang banyak. Sistem penggaraman rakyat sampai saat ini menggunakan kristalisasi total sehingga produktifitas dan kualitasnya masih kurang atau pada umumnya kadar NaClnya kurang dari $90 \%$ dan banyak mengandung pengotor padahal luas lahan penggaraman rakyat $25.542 \mathrm{Ha}$ atau sekitar $83,31 \%$ dari luas areal penggaraman nasional. Jika 50\% dari luas areal penggaraman ini ditingkatkan produktifitasnya menjadi 80 ton/Ha/tahun, maka dapat diproduksi garam sebanyak 1.500.000 ton sehingga total produksi garam nasional menjadi 1.800.000 ton. Dengan demikian kebutuhan impor garam industri dapat dikurangi dari 1.200.000 ton menjadi hanya sekitar 300.000 ton (Purbani, 2010).

Dengan demikian perlu adanya kajian studi tentang pemberdayaan usaha garam rakyat
(PUGAR) untuk mensukseskan program swasembada garam industri tahun 2015. Program tersebut akan dioptimalkan dengan proses produksi berbasis suistanable manufaktur dan pengolahan air reserve osmosis berbasis mikrokontroler (Rachmawati, 2010). Proses produksi berbasis sustainable manufacturing merupakan pengoptimalan proses dari hulu ke hilir sehingga keberlanjutan proses produksi dan produktivitas meningkat.

\section{Perumusan Masalah}

Berdasarkan latar belakang tersebut di atas, maka dirumuskan sebagai berikut:

a) Menganalisis pemberdayaan usaha garam rakyat (PUGAR) berdasarkan aspek produksi, distribusi, permintaan garam industri Jawa Tengah.

b) Menentukan tingkat pemberdayaan usaha garam rakyat di wilayah Jawa Tengah

\section{Metode Penelitian}

Penelitian ini dilakukan pada usaha garam rakyat di wilayah Jawa Tengah, antara lain : Demak, Kudus dan Rembang. Populasi dan sampel penelitian adalah Usaha garam rakyat yang berjumlah 30 .

\section{Metode Pengumpulan Data}

Pengumpulan data yang dilakukan meliputi (1) Kuesioner (2) FGD (3) Wawancara Mendalam. Focused Group Discussion (FGD) yang dilakukan melibatkan para pelaku usaha garam pemerintah yang membuat regulasi. Wawancara mendalam dilakukan dengan 11 keypersons yang kompeten, terdiri dari pelaku usaha garam Jawa Tengah, Pemerintah, Asosiasi, Lembaga akademisi.

\section{Teknik Alat Analisis \\ Analisis tingkat Keberdayaan}

Untuk menganalisis tingkat keberdayaan UKM GaramJawa Tengah digunakan analisis deskriptif. Tingkat keberdayaan UKM GaramJawa Tengah dilihat dari akses terhadap produksi, distribusi, permintaan pasar dan sosial budaya.

\section{Analisis Strategi Pemberdayaan}

Langkah untuk menentukan strategi pemberdayaan UKM Garam di Jawa Tengah adalah sebagai berikut:

a) Focus Group Discussion (FGD) dilakukan guna memeroleh informasi mengenai pemberdayaan UKM garamJawa Tengah. Peserta FGD meliputi pelaku usaha garamJawa Tengah, pemerintah yang membuat regulasi (Dinas Kelautan dan Perikanan, DISPERINDAG Kota Jawa Tengah, dan paguyupan petani garam)

b) Wawancara mendalam (In depth Interview) dengan Keypersons yang berkompeten. 


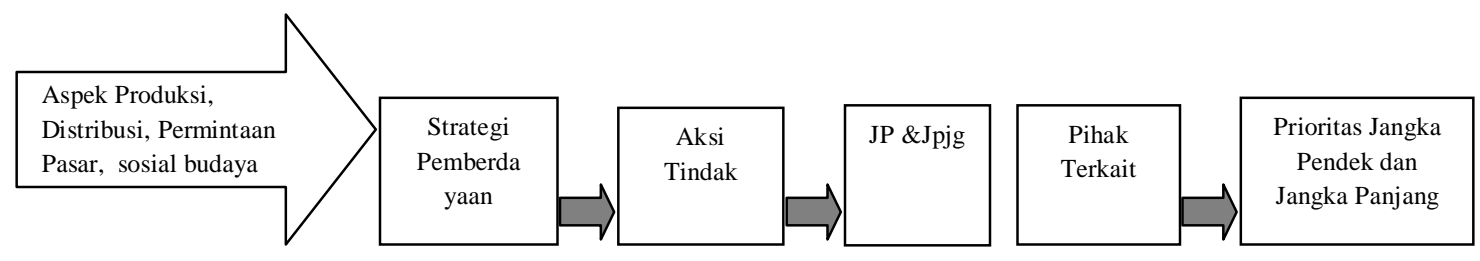

Gambar 1. Model Pemberdayan

\section{Model Pemberdayaan Usaha Garam Rakyat di Jawa Tengah \\ Berdasarkan strategi pemberdayaan, maka dapat dirumuskan model pemberdayaan UKM Garam di Jawa Tengah. Model pemberdayaan peningkatan kinerja UKM Garam di Jawa Tengah. Model pemberdayaan usaha garam seperti gambar 1 .}

\section{Hasil dan Pembahasan}

Kuisioner pemberdayaan usaha garam rakyat disebarkan di wilayah Jawa Tengah khususnya daerah Demak, Kudus dan Rembang. Daerah-daerah tersebut merupakan sentra produksi garam seperti ditampilkan pada Gambar 2 dan Gambar 3. Jumlah kuesioner yang dibagikan kepada responden sebanyak 40 kuesioner, dan yang kembali hanya 30 responden. Tingkat pengembalian sebesar $75 \%$ seperti pada Gambar 4.

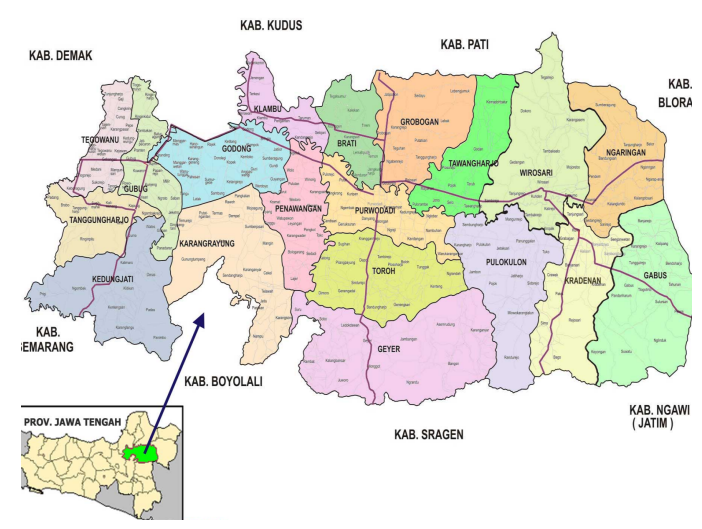

Gambar 2. Peta Demak dan Kudus

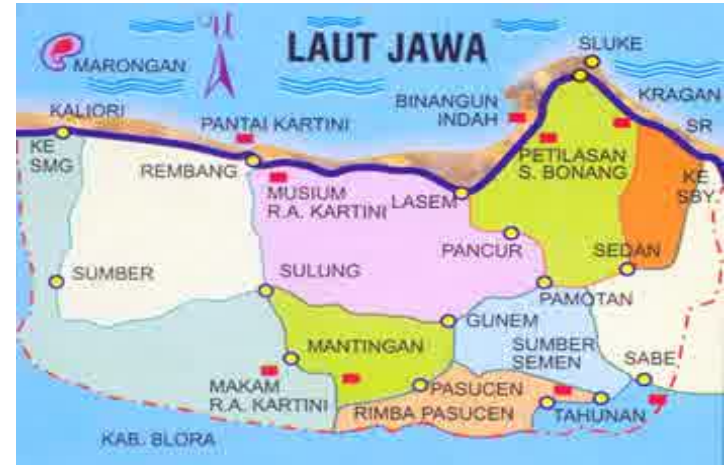

Gambar 3. Pera daerah Rembang

J@TI Undip, Vol X, No.1, Januari 2015
Tabel 1. Hasil kuisioner

\begin{tabular}{cc}
\hline Keterangan & Jml \\
\hline Kuesioner disebar & 40 \\
Kuesioner kembali & 30 \\
$\begin{array}{c}\text { Tingkat Kembalian } \\
\text { Responden }\end{array}$ & $75 \%$ \\
\hline Sumber : Data primer yang diolah, 2013
\end{tabular}

—uisioner kembali $\quad$ Kuisioner tidak kembali

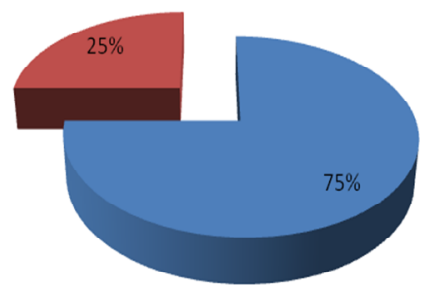

Gambar 4. Tingkat pengembalian kuisioner (prosentase)

Objek yang teliti merupakan usaha garam rakyat yang berbentuk industri rumah tangga. Proses pengolahan dilakukan di lahan dan memiliki gudang penyimpanan seperti pada Gambar 5.

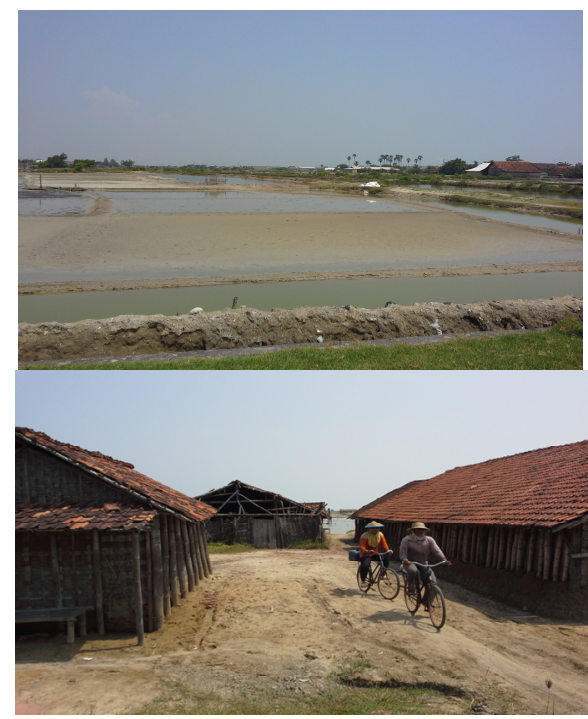

Gambar 5. Lahan pengolahan air garam dan gudang penyimpanan garam 
Tingkat Keberdayaan Usaha garam rakyat

Tingkat keberdayaan industri usaha garam di Jawa Tengah dianalisis melalui analisis diskriptif. Pengukuran tingkat keberdayaan tersebut dilakukan melalui beberapa aspek yang sangat penting untuk menunjukkan tingkat keberdayaan kinerja pengrajin Usaha garam rakyat. Aspek yang diukur meliputi aspek produksi, aspek distribusi, aspek permintaan pasar dan aspek sosial budaya.

Dari hasil penelitian ditunjukkan masing-masing aspek sebagai berikut :

Aspek Produksi

Jenis garam yang banyak diproduksi adalah garam bahan baku industri, pola produksi mass production dengan dominasi area pasar local, meskipun bebrapa usaha telah memasuki pasar nasional. Dalam menjalankan usaha hanya sedikit yang memperoleh bantuan kredit. Peningkatan modal awal setelah menjalankan usaha berkisar $30 \%$. Usaha beroperasi tergantung pada cuaca/musim. Bila musim mendukung (panas) hari kerja selama 6-7 hari per minggu dengan jam kerja 5-6 jam per hari. Memproduksi garam bahan baku industri relatif lebih singkat disbanding garam olahan konsumsi dengan selisih waktu 15-20 hari.

Tingkat keberdayaan aspek produksi dapat dijelaskan melalui tabel 2 .

Tabel 2. Tingkat keberdayaan Aspek Produksi

\begin{tabular}{lc}
\hline & PERSENTASE TINGKAT \\
ASPEK PRODUKSI & KEBERDAYAAN \\
\hline BAHAN BAKU & \\
$\begin{array}{l}\text { Stok Bahan baku } \\
\text { banyak }\end{array}$ & 100 \\
$\begin{array}{l}\text { Kemudahan } \\
\text { mendapatkan }\end{array}$ & 100 \\
$\begin{array}{l}\text { Harga Bahan baku } \\
\text { murah }\end{array}$ & 23,33 \\
$\begin{array}{l}\text { Kualitas bahan baku } \\
\text { baik }\end{array}$ & 73,33 \\
$\begin{array}{l}\text { Ketersediaan pengganti } \\
\text { bahan baku }\end{array}$ & 0 \\
$\begin{array}{l}\text { Rata-rata } \\
\text { TENAGA KERJA }\end{array}$ & 59,33 \\
$\begin{array}{l}\text { Tenaga Kerja banyak } \\
\text { tersedia } \\
\begin{array}{l}\text { Tenaga Kerja Mudah } \\
\text { didapat }\end{array}\end{array}$ \\
$\begin{array}{l}\text { Upah Tenaga Kerja } \\
\text { murah }\end{array}$ \\
\begin{tabular}{l} 
Kualitas kerja baik \\
\hline
\end{tabular}
\end{tabular}

J@TI Undip, Vol X, No.1, Januari 2015

\begin{tabular}{|c|c|c|}
\hline $\begin{array}{l}\text { ketrampilan mudah } \\
\text { ditingkatkan }\end{array}$ & 66,67 & \\
\hline Rata-rata & 72,00 & \\
\hline \multicolumn{3}{|l|}{ MODAL } \\
\hline $\begin{array}{l}\text { butuh banyak modal } \\
\text { usaha }\end{array}$ & 50,00 & \\
\hline $\begin{array}{l}\text { modal usaha mudah } \\
\text { didapatkan }\end{array}$ & 43,33 & \\
\hline biaya modal terjangkau & 40,00 & Rendah \\
\hline $\begin{array}{l}\text { alternatif sumber modal } \\
\text { banyak }\end{array}$ & 40,00 & \\
\hline $\begin{array}{l}\text { modal mudah dialihkan } \\
\text { untuk usaha lain }\end{array}$ & 6,67 & \\
\hline Rata-rata & 36,00 & \\
\hline
\end{tabular}

\section{TEKNOLOGI}

Teknologi terapan \& modern

Alat modern/canggih mudah didapatkan

Harga alat modern terjangkau 3,33 Rendah

Alternatif teknologi tersedia

Ketrampilan SDM meningkat

Rata-rata 21,33

Sumber: Data Primer Yang Diolah, 2013

$\underline{\text { Aspek Distribusi }}$

Penjualan masih didominasi pasar lokal dibanding nasional, dengan jumlah produksi garam bahan baku dan atau garam olahan konsumsi berkisar antara $50 \mathrm{Kg}$ hingga 300 ton per musim. Pasar lokal meliputi Pekalongan, Tegal, Cilacap, Jepara, Demak, Kudus,dll. Sedangkan untuk pasar regional pernah menjual produk hingga wilayah Sumatra. Usaha garam yang menjual produk di wilayah lokal sebanyak 50-100\%, sedangkan untuk pasar regional/nasional hanya $40 \%$ saja.

Tingkat Keberdayaan aspek produksi diukur melalui jangkauan pasar, kemudahan menjual, dan tersedianya saluran distribusi. Sebagian produsen usaha garam rakyat masih memasarkan hasil produksinya di wilayah lokal dan beberapa kota sekitarnya. Pemasaran usaha garam semarang belum banyak hingga ke tingkat nasional ataupun internasional. Hanya $40 \%$ responden yang melakukan pemasaran hingga tingkat nasional.Untuk di tingkat internasional pun belum dilakukan secara kontinyu.

Jika dilihat kemudahan menjual produk usaha garam rakyat, produsen masih merasa kesulitan. Hanya $50 \%$ yang menyatakan mudah untuk menjual 
produknya. Sedangkan saluran distribusi yang digunakan masih menjual secara langsung dengan konsumen. Hanya sebanyak 43,3\% responden yang telah memiliki saluran distribusi yang baik.

\section{Aspek Usaha dan permintaan pasar}

Aspek permintaan pasar diukur melalui segmen pasar industri usaha garam rakyat, bentuk produksi untuk memenuhi permintaan konsumen, daya saing harga dan pengetahuan tentang informasi kebutuhan pasar. Pengadaan produksi usaha garam dilakukan secara masal atau secara pesanan (order). Hasil identifikasi keberdayaan usaha garam pada indikator harga, menunjukkan bahwa responden yang menyatakan bahwa harga produk usaha garam dapat bersaing hanya sebesar $23 \%$. Selebihnya menyatakan tidak dapat bersaing. Sedangkan pengetahuan responden mengenai informasi kebutuhan pasar masih rendah, yaitu sebesar $20 \%$.

Dari hasil identifikasi keberdayaan usaha garam pada aspek permintaan pasar dapat disimpulkan bahwa tingkat keberdayaannya masih dapat dikatakan rendah.

\section{Aspek sosial budaya dan keberlanjutan usaha}

Keberlanjutan usaha garam dan semangat pengusaha garam untuk ingin tetap menjalankan usaha tergolong tinggi. Namun masih terkendala musim dalam berproduksi sehingga terjadi pergantian mata pencaharian saat musim hujan tiba.

Berdasarkan keempat aspek tersebut diatas dapat disimpulkan bahwa aspek produksi,aspek distribusi dan permintaan pasar tergolong rendah. Namun keberlanjutan usaha tergolong tinggi. Oleh sebab itu diperlukan strategi pemberdayaan yang mampu mengatasi permasalahan di ketiga aspek tersebut sehingga keberlanjutan usaha garam dan keberdayaan usaha garam meningkat.

\section{Strategi Pemberdayaan}

Berdasarkan beberapa tanggapan mengenai tingkat keberdayaan pengrajin usaha garam rakyat pada Focus Discussion Group (FGD) yang dilakukan dari berbagai pihak, maka dapat dirumuskan strategi pemberdayaan kinerja usaha garam rakyat. Strategi pemberdayaan meliputi aspek produksi, aspek distribusi, aspek permintaan pasar, dan aspek sosial budaya.

\section{Aspek Produksi}

1. Strategi pemberdayaan kinerja usaha garam rakyat pada aspek produksi meliputi :

2. Tersedianya teknologi terapan dalam proses produksi yang tidak tergantung musim/cuaca

3. Pemberian bantuan modal usaha yang tepat sasaran

4. Penyelenggaraan pelatihan produksi usaha garam secara kontinyu

5. Tersedianya alternatif teknologi pengolahan garam untuk meningkatkan kuantitas dan kualitas produk garam.

\section{Aspek Distribusi}

Strategi pemberdayaan kinerja usaha garam rakyat pada aspek distribusi meliputi :

1. Perbaikan sistem distribusi

2. Bantuan promosi baik secara lokal, nasional maupun internasional

3. Meningkatkan kerjasama tata niaga/misi dagang

4. Perlu dukungan pemerintah promosi produk garam lokal dan mengurangi import garam

\section{Aspek Permintaan Pasar} Strategi pemberdayaan kinerja usaha garam rakyat pada aspek permintaan pasar meliputi :

1. Penguasaan informasi pasar baik lokal dan nasional

2. Pemenuhan spesifikasi produk untuk memenuhi keinginan konsumen

3. Pemenuhan kualitas dan kuantitas garam sesuai keinginan konsumen

\section{Aspek Sosial Budaya}

Strategi pemberdayaan kinerja usaha garam Semarang pada aspek sosial budaya meliputi :

1. Terciptanya iklim usaha yang kondusif terutama dalam persaingan harga

2. Menciptakan budaya mencintai garam dalam negeri bagi masyarakat

3. Fasilitasi pemerintah penentuan

\section{Model Pemberdayaan Kinerja Usaha Usaha garam rakyat}

Peningkatan kinerja usaha usaha garam rakyat salah satunya ditentukan oleh ketepatan dan keberhasilan strategi pemberdayaan yang dilakukan. Model pemberdayaan kinerja bagi pengrajin usaha garam rakyat dirumuskan berdasarkan proses diskusi. Model pemberdayaan tersebut meliputi aspek produksi, aspek distribusi, aspek permintaan pasar, dan aspek sosial budaya. Model pemberdayaan dari masing-masing aspek dapat dijelaskan melalui strategi, aksi tindak, pihak terkait dan prioritas pencapaian.

\section{Aspek Produksi}

Model pemberdayaan kinerja usaha usaha garam rakyat pada aspek produksi dapat dijelaskan melalui Tabel 3. 
Tabel 3. Model Pemberdayaan Kinerja Usaha Usaha garam melalui Aspek Produksi

\begin{tabular}{|c|c|c|c|c|}
\hline Strategi & Aksi Tindak & Pihak Terkait & Jangka Pendek & Jangka Panjang \\
\hline $\begin{array}{l}\text { Tersedian ya teknologi } \\
\text { produksi yang tidak } \\
\text { tergantung musim } \\
\text { Pemberian bantuan } \\
\text { modal usaha yang tepat } \\
\text { sasaran } \\
\text { Penyelenggaraan } \\
\text { pelatihan produksi } \\
\text { usaha garam secara } \\
\text { Kontinyu } \\
\text { Tersedianya teknologi } \\
\text { alternatif }\end{array}$ & $\begin{array}{l}\text { Bantuan teknologi } \\
\text { terapan produksi garam } \\
\text { tidak tergantung musim } \\
\text { Bantuan modal tepat } \\
\text { t sasaran secara finansial } \\
\text { dan non } \\
\text { Finansial } \\
\text { Pelatihan manajemen } \\
\text { keuangan bagi pengrajin } \\
\text { Kerjasama dengan pihak } \\
\text { akademik dalam proses } \\
\text { desain alat produksi } \\
\text { garam yang tidak } \\
\text { tergantung cuaca }\end{array}$ & $\begin{array}{l}\text { Pemerintah } \\
\text { Lembaga Penelitia } \\
\text { Akademisi } \\
\text { Pelaku bisnis } \\
\text { Lembaga } \\
\text { Keuangan } \\
\text { Konsultan bisnis } \\
\text { Perusahaan } \\
\text { a Lembaga sosial } \\
\text { kkemasyarak } \\
\text { atan/ Perkumpulan } \\
\text { petani garam }\end{array}$ & $\begin{array}{l}\text { Melakukan } \\
\text { pemberdayaan } \\
\text { melalui : } \\
\text { Menjalin kerjasama } \\
\text { dengan akademisi dan } \\
\text { LIPI terkait teknologi } \\
\text { dan alat produksi } \\
\text { Pelatihan proses } \\
\text { produksi } \\
\text { Bantuan modal baik } \\
\text { sec finansial maupun } \\
\text { non finansial. }\end{array}$ & $\begin{array}{l}\text { Melakukan } \\
\text { pemberdayaan } \\
\text { melalui : } \\
\text { Bantuan modal } \\
\text { berkelanjutan } \\
\text { Pelatihan } \\
\text { manajemen dan } \\
\text { teknologi usaha } \\
\text { garam secara } \\
\text { berkelanjutan } \\
\text { Meningkatkan } \\
\text { kerjasama dengan } \\
\text { akademisi dan } \\
\text { lembagapenelitian } \\
\text { pemerintah secara } \\
\text { berkelanjutan }\end{array}$ \\
\hline
\end{tabular}

\section{Aspek Distribusi}

Tabel 4. Model Pemberdayaan Kinerja Usaha garam melalui Aspek Distribusi

\begin{tabular}{|c|c|c|c|c|}
\hline Strategi & Aksi Tindak & PihakTerkait & Jangka Pendek & Jangka Panjang \\
\hline $\begin{array}{l}\text { Perbaikan sistem } \\
\text { distribusi } \\
\text { Bantuan promosi baik } \\
\text { secaralokal \& nasional } \\
\text { Meningkatkan } \\
\text { kerjasama tata niaga/ } \\
\text { misi dagang } \\
\text { Dukungan pemerintah } \\
\text { support garam lokal }\end{array}$ & $\begin{array}{l}\text { Koordinasi dan } \\
\text { perbaikan sistem } \\
\text { distribusi } \\
\text { Memberikan } \\
\text { informasi tentang } \\
\text { peluang pasar dalam } \\
\text { negeri } \\
\text { Kerjasama dengan } \\
\text { agen/pedagang besar } \\
\text { Menciptakan dan } \\
\text { mengoptimalkan } \\
\text { perkumpulan petani } \\
\text { garam } \\
\text { Optimalisasi } \\
\text { penggunaan garam } \\
\text { lokal dari pada garam } \\
\text { import }\end{array}$ & $\begin{array}{l}\text { Pemerintah } \\
\text { Konsultan bisnis } \\
\text { Perusahaan } \\
\text { Akademisi } \\
\text { Lembaga sosial } \\
\text { masyarakat } \\
\text { /Perkumpulan } \\
\text { petani garam }\end{array}$ & $\begin{array}{l}\text { Melakukan } \\
\text { pemberdayaan melalui : } \\
\text { Berantas tengkulak yang } \\
\text { mengendalikan harga } \\
\text { Bantuan promosi } \\
\text { penjualan\& distribusi } \\
\text { garam lokal Indonesia } \\
\text { Memberikan informasi } \\
\text { peluang } \\
\text { pasar }\end{array}$ & $\begin{array}{l}\text { Melakukan } \\
\text { gemberdayaan melalui } \\
\text { g perbaikan rantai } \\
\text { distribusi } \\
\text { secaraberkelanjutan } \\
\text { Bantuan promosi } \\
\text { berkelanjutan } \\
\text { Pengurangan import } \\
\text { garam secara bertahap } \\
\text { hingga produk garam } \\
\text { lokal Indonesia } \\
\text { berperan besar } \\
\text { memenuhi permintaan } \\
\text { garam nasional } \\
\text { Pemerintah membantu } \\
\text { meciptakan cluster } \\
\text { usaha garam rakyat }\end{array}$ \\
\hline
\end{tabular}




\section{Aspek Permintaan Pasar}

Tabel 5. Model Pemberdayaan Kinerja Usaha garam melalui Aspek Permintaan Pasar

\begin{tabular}{|c|c|c|c|c|}
\hline Strategi & Aksi Tindak & Pihak Terkait & Jangka Pendek & Jangka Panjang \\
\hline $\begin{array}{l}\text { Penguasaan informasi } \\
\text { pasar lokal \& nasional } \\
\text { Pemenuhan } \\
\text { spesifikasi produk } \\
\text { untuk memenuhi } \\
\text { keinginan } \\
\text { konsumen } \\
\text { Peningkatan kuantitas } \\
\text { dan kualitas garam }\end{array}$ & $\begin{array}{l}\text { Pemberian informasi } \\
\text { pasar baik lokal \& } \\
\text { nasional maupun } \\
\text { internasional } \\
\text { Mengajak para } \\
\text { pengusaha/petani } \\
\text { garam untuk } \\
\text { memperhatikan/men } \\
\text { gikuti keinginan } \\
\text { konsumen } \\
\text { (rasa,ukuran, dan } \\
\text { kualitas beragam } \\
\text { Menggalang } \\
\text { pemakaian produksi } \\
\text { usaha garam } \\
\text { produksi lokal pada } \\
\text { kalangan pemerintah } \\
\text { dan masyarakat. } \\
\text { Memberikan } \\
\text { informasi dan } \\
\text { bantuan teknologi / } \\
\text { alat untuk } \\
\text { peningkatan } \\
\text { kuantitas dan } \\
\text { kualitas garam }\end{array}$ & $\begin{array}{l}\text { Pemerintah } \\
\text { Perusahaan } \\
\text { Akademisi } \\
\text { Lembaga sosial } \\
\text { masyarakat/ } \\
\text { Perkumpulan petani } \\
\text { garam }\end{array}$ & $\begin{array}{l}\text { Melakukan } \\
\text { pemberdayaan melalui } \\
: \\
\text { Pemenuhan spesifikasi } \\
\text { produk sesuai } \\
\text { keinginan konsumen } \\
\text { Pemberian informasi } \\
\text { pasar baik lokal, } \\
\text { nasional maupun } \\
\text { internasional } \\
\text { Pelatihan peningkatan } \\
\text { kualitas dan kuantitas } \\
\text { garam }\end{array}$ & $\begin{array}{l}\text { Melakukan } \\
\text { Pemberdayaan melalui: } \\
\text { Informasi pasar yang } \\
\text { berkelanjutan } \\
\text { Penggunaan produk } \\
\text { garam lokal oleh } \\
\text { pemerintah dan } \\
\text { masyarakat } \\
\text { secara berkelanjutan } \\
\text { 3antuan aplikasi } \\
\text { teknologi terapan untuk } \\
\text { memperbaiki kuantitas } \\
\text { dan kualitas garam }\end{array}$ \\
\hline
\end{tabular}

\section{Aspek Sosial Budaya}

Tabel 6. Model Pemberdayaan Kinerja Usaha garam melalui Aspek Sosial Budaya

\begin{tabular}{|c|c|c|c|c|}
\hline Strategi & Aksi Tindak & Pihak Terkait & Jangka Pendek & Jangka Panjang \\
\hline $\begin{array}{l}\text { Terciptanya iklim usah } \\
\text { yang kondusif } \\
\text { Menciptakan budaya } \\
\text { penggunaan garam } \\
\text { lokal Indonesia bagi } \\
\text { masyarakat } \\
\text { Fasilitasi pemerintah } \\
\text { dalam penentuan } \\
\text { persaingan harga }\end{array}$ & $\begin{array}{l}\text { Merancang peraturan } \\
\text { daerah } \\
\text { tentang perlindungan } \\
\text { dan keberlangsungan } \\
\text { industri garam rakyat } \\
\text { Sosialisasi peraturan } \\
\text { daerah kepada } \\
\text { masyarakat } \\
\text { Implementasi dan } \\
\text { evaluasi peraturan } \\
\text { daerah budaya } \\
\text { Menggalakkan garam } \\
\text { menggunakan } \\
\text { lokal Indonesia pada } \\
\text { masyarakat } \\
\text { Pemerintah bersama } \\
\text { akademisi memberikan } \\
\text { pelatihan industri usaha } \\
\text { garam. }\end{array}$ & $\begin{array}{l}\text { Pemerintah } \\
\text { Perusahaan } \\
\text { Akademisi } \\
\text { Lembaga sosial } \\
\text { masyarakat } \\
\text { /Perkumpulan petani } \\
\text { garam } \\
\\
\text { A } \\
\end{array}$ & $\begin{array}{l}\text { Melakukan } \\
\text { pemberdayaan melalui } \\
\text { Pemerintah } \\
\text { memberikan jaminan } \\
\text { stabilitas usaha } \\
\text { Menggalakkan budaya } \\
\text { menggunakan garam } \\
\text { lokal Indonesia secara } \\
\text { berkelanjutan }\end{array}$ & $\begin{array}{l}\text { Melakukan } \\
\text { : pemberdayaan } \\
\text { melalui : } \\
\text { Merancang roadmap } \\
\text { industri usaha garam } \\
\text { guna merancang } \\
\text { peraturan daerah } \\
\text { tentang industri } \\
\text { garam } \\
\text { Melaksanakan } \\
\text { sosialisasi peraturan } \\
\text { daerah } \\
\text { Mengurangi } \\
\text { ketergantungan garam } \\
\text { import secara } \\
\text { berkelanjutan }\end{array}$ \\
\hline
\end{tabular}




\section{Kesimpulan}

Aspek Produksi secara keseluruhan menunjukkan hasil empat indikator memiliki tingkat keberdayaan yang tinggi, yaitu sebesar $59,33 \%$ dan tenaga kerja memiliki tingkat pemberdayaan tinggi yaitu $72 \%$. Sedangkan modal memiliki tingkat pemberdayaan rendah yaitu 36\% dan teknologi terapan dan modern memiliki tingkat pemberdayaan yang rendah yaitu $21,33 \%$.

Aspek Distribusi secara keseluruhan juga menunjukkan hasil yang rendah $(<50 \%)$, baik dari indikator jangkauan pasar dan kemudahan menjual produk.

Tingkat keberdayaan aspek permintaan pasar dapat dijelaskanbahwa harga produk usaha garam dapat bersaing hanya sebesar $23 \%$. Selebihnya menyatakan tidak dapat bersaing. Sedangkan pengetahuan responden mengenai informasi kebutuhan pasar masih rendah, yaitu sebesar $20 \%$.

Aspek sosial budaya ditunjukkan dengan kemudahan responden dalam melestarikan usaha garam dan keikutsertaan dalam aktivitas paguyuban usaha garam rakyat yang masih tinggi. (> 50\%). Keberlanjutan usaha garam dan semangat pengusaha garam untuk ingin tetap menjalankan usaha tergolong tinggi. Namun masih terkendala musim dalam berproduksi yang tergantung cuaca sehingga kuantitas garam tidak maksimal.

Model Pemberdayaan Kinerja usaha usaha garam rakyat didasarkan pada aspek produksi, aspek distribusi, aspek permintaan pasar dan aspek sosial budaya yang terdiri dari strategi, aksi tindak, pihakpihak yang terkait, dan prioritas jangka pendek dan prioritas jangka panjang. Dengan prioritas jangka pendek adalah optimalisasi teknologi terapan untuk proses produksi, perbaikan rantai distribusi dan informasi pasar yang berkelanjutan sehingga tercipta stabilitas usaha garam rakyat.

\section{Daftar Pustaka}

Anomsari, A dan Setyaningrum, R (2013). Implementasi model pemberdayaan UKM batik dalam upaya mengangkat kearifan local batik di Semarang. Hibah Bersaing.

Kompas.com. Tanggal akses 26 September 2012. Garam sesuai standart mutu.

Predeep (2013). Make the most of your energy. International Seminar of Industrial and Management.

Purbani (2010). Proses pembentukan kristalisasi garam. Dinas kelautan dan perikanan.

Rachmawati,R., Dianti,Z.T dan Eko, H (2010). Otomatisasi system pengolahan air laut menjadi air tawar dengan prinsip reverses osmosis berbasis mikrokontroler.Skripsi.ITS.

Rosnah, Y (2013). Innovation ini manufacturing for sustainable growth.

International Seminar of Industrial and Management. 